\title{
Adrenergic Agonist
}

National Cancer Institute

\section{Source}

National Cancer Institute. Adrenergic Agonist. NCI Thesaurus. Code C87053.

Any agent that binds to and activates any of the adrenergic receptors. 